\title{
Dual-task during gait between elderly with mild cognitive impairment and Alzheimer: systematic review
}

\author{
Dupla tarefa durante a marcha entre idosos com comprometimento \\ cognitivo leve e Alzheimer: revisão sistemática
}

\author{
Vanessa Santa Rosa Bragatto, Larissa Pires de Andrade, Paulo Giusti Rossi, Juliana Hotta Ansai*
}

Universidade Federal de São Carlos (UFSCar), São Carlos, SP, Brazil

\begin{abstract}
Introduction: Studies reportthatmobility changes could bepresentin early stages ofAlzheimer's disease (AD) or even in previous stages, such as mild cognitive impairment (MCI). The use of motor tests, involving dual task, could facilitate screening and differentiation between elderly with AD and MCI. Objective: to verify if gait tests associated with secondary tasks could differentiate elderly with AD and MCI. Methods: We conducted a systematic review in Pubmed, Web of Science, Medline and Scielo databases. Of the articles included, we collected information about year of the study, characteristics of the sample and the dual task test studied. Results: The databases were accessed during November 2014 and August 2015 and a total of 198 scientific papers was obtained. After reading first the summaries and then the full texts, five studies were inserted in the review. Elderly with AD presented a reduction of gait speed and stride length, using executive functions and countdown as secondary cognitive tasks. The type of MCI appears to influence the differentiation with AD. Conclusion: The review showed that some gait tests associated with a secondary task differentiate elderly with AD and MCI. It emphasizes the need of new studies involving this issue in order to obtain cut-off points and facilitate prevention, early diagnosis and observation of cognitive impairment's evolution in clinical practice of elderly.
\end{abstract}

Keywords: Cognition. Dementia. Aged. Gait.

\footnotetext{
* VSRB: BS, e-mail: vsrbfisio@gmail.com LPA: PhD, e-mail: larissa.andrade@ufscar.br PGR: Doctoral student, e-mail: paulo.giusti.rossi@gmail.com JHA: Doctoral student, e-mail: julianaansai@gmail.com
} 
Resumo

Introdução: Estudos relatam que alterações da mobilidade podem estar presentes em fases iniciais da doença de Alzheimer (DA) ou mesmo em estágios prévios como o comprometimento cognitivo leve (CCL). O uso de testes motores, envolvendo dupla tarefa, pode facilitar o rastreio e a diferenciação entre idosos com CCL de DA. Objetivo: verificar se testes de marcha associada a tarefas secundárias conseguiriam diferenciar idosos com CCL de DA. Métodos: Para isso, realizou-se uma revisão bibliográfica sistemática nas bases de dados Pubmed, Web of Science, Medline e Scielo. Dos artigos incluídos, foram coletados informações quanto ao ano do estudo, dados da amostra avaliada e teste de dupla tarefa utilizada. Resultados: As bases de dados foram acessadas durante novembro de 2014 e agosto de 2015, sendo obtidos ao todo 198 textos científicos. Após a leitura primeiramente dos resumos, posteriormente dos textos completos, foram inseridos cinco artigos para a revisão. Dos artigos inseridos, observou-se redução da velocidade da marcha e comprimento do passo em idosos com $D A$, utilizando funções executivas e contagem recressiva como tarefas cognitivas secundárias. $O$ tipo de CCL parece influenciar na diferenciação com DA. Conclusão: A revisão mostrou que há testes de marcha associada a uma tarefa que diferenciam idosos com CCL de DA. Enfatiza-se a realização de novos estudos envolvendo essa temática com o intuito de obter notas de corte e facilitar medidas de prevenção, diagnóstico precoce e observação da evolução da alteração cognitiva na prática clínica de idosos.

Palavras-chave: Cognição. Demência. Idoso. Marcha.

\section{Introduction}

Alzheimer's disease (AD) is a chronic degenerative dementia that affects the central nervous system. Initially, there is loss of memory for recent events, and later changes in other cognitive functions, such as language and executive function, as well as in social and functional activities occur $(1,2)$.

Mild Cognitive Impairment (MCI) is an intermediate state between normal aging and AD. The most common cognitive impairment is related to episodic memory, but people with MCI do not present functional deficit and may develop to $\mathrm{AD}$ or not $(3,4)$. The prevalence of MCI varies between $3 \%$ and $19 \%$ among elderly people, depending on their age and educational level. The conversion rate of MCI to AD or other type of dementia ranges from 10 to 15\% (5).

Besides cognitive and functional changes, motor impairments can be found in people with AD (6). Gait disturbances, such as reduced gait speed, stride length and stride width, can be seen in early stages of dementia or even in preclinical stages of $\operatorname{AD}(7,8)$. Moreover, about $60 \%$ of elderly people with cognitive impairment suffer twice more falls compared to elderly people with preserved cognition (9). Such motor impairments can result in loss of independence and quality of life (10).
Gait was considered as an automatic motor task in elderly people. However, Montero-Odasso et al. (11) suggested that this view is simplistic and, in fact, cognitive function has a central role in regulating gait. Cognitive control on gait becomes more evident in elderly people with cognitive impairment and during activities involving two tasks simultaneously (dual task).

In situations involving gait and a secondary task, both tasks interfere and compete for cortical brain resources. The lack of cortical control on stride adjustment has been associated with an increased risk of falls. The dual task is clinically relevant, because most daily activities include the simultaneous execution of two or more cognitive and motor tasks (11). Gait associated with a cognitive task has been used to distinguish elderly people with preserved cognition, $\mathrm{MCI}$ and $\mathrm{AD}(11$ - 14). However, there is a need to confirm if dual task tests can distinguish or not elderly people with $\mathrm{MCI}$ from $\mathrm{AD}$, mainly in the mild phase of AD, as well as information about the type of cognitive task chosen, cut-off scores and validated tests.

In Brazil, there are some cognitive tools validated to screen dementia and to monitor its evolution, such as the Mini Mental State Examination (15) and the Addenbrooke's Cognitive Examination (16). However, the use of motor tests involving dual task could facilitate the screening and the differentiation between 
elderly people with $\mathrm{MCI}$ and $\mathrm{AD}$, mainly in the mild phase. Since MCI can revert to normal or stabilize, a better differentiation between these populations could facilitate prevention of dementia, early diagnosis and attendance of evolution in clinical practice (1).

Therefore, the purpose of this study was to verify if tests involving gait associated with a secondary task could differ elderly people with MCI from AD.

\section{Methods}

A systematic review of national and international literature was conducted, without protocol registration, using articles in the electronic databases of Pubmed, Medline, Scielo and Web of Science. The review was done using the START software (version 2.3.3). Databases were accessed between November 2014 and August 2015.

As keywords, we used the following combination in Pubmed and Web of Science databases: "Mild Cognitive Impairment", ("Alzheimer Disease" or dementia), ("dual task" or gait or walking) and aged. For Medline and Scielo databases, the following combination of keywords was used: ("Mild Cognitive Impairment" or "comprometimento cognitivo leve"), ("Alzheimer Disease" or "Doença de Alzheimer" or dementia or demência), ("dual task" or "dupla tarefa" or gait or walking or marcha) and (aged or idoso).

Inclusion criteria were articles published between 2000 and 2015, articles involving dual task instruments, cross-sectional studies, English or Portuguese languages and presenting a $\mathrm{MCI}$ or $\mathrm{AD}$ medical diagnosis. Exclusion criteria were sample with a mean age under 60 years, dual task tests that did not assess gait, clinical trials, studies that did not aim to assess dual task instruments to differ elderly people with $\mathrm{MCI}$ from $\mathrm{AD}$ and animal studies.

Initially, a single researcher carried the first selection through summaries found in the search. After that, the second selection was carried out by two researchers, who read the full texts of the articles. In cases of disagreement among researchers about the acceptance of an article, it was judged by a third researcher and a consensus on its acceptance or rejection was done.
From articles included, information about year of study, characteristics of sample (mean age, number of subjects, type of population and medical diagnosis of MCI and AD) and dual task test used (type of task, procedures, validation, translation, reproducibility and cut-off score) were collected.

\section{Results}

A total of 198 articles was obtained in the search and, of these, 43 were duplicated. Specifically, 130 articles in Web of Science, 68 in PubMed and no article in Medline and Scielo databases were found. After the first selection by reading abstracts, 18 articles were selected. After the second selection by reading full text, there was conflict between researchers about the acceptance of only three studies. At the end, 13 articles were excluded and five articles were selected to this review, as shown on a flow diagram (Figure 1).

Among the five articles included, the publication years ranged from 2008 to 2012 and all texts were in English. Table 1 shows the main findings of included articles.

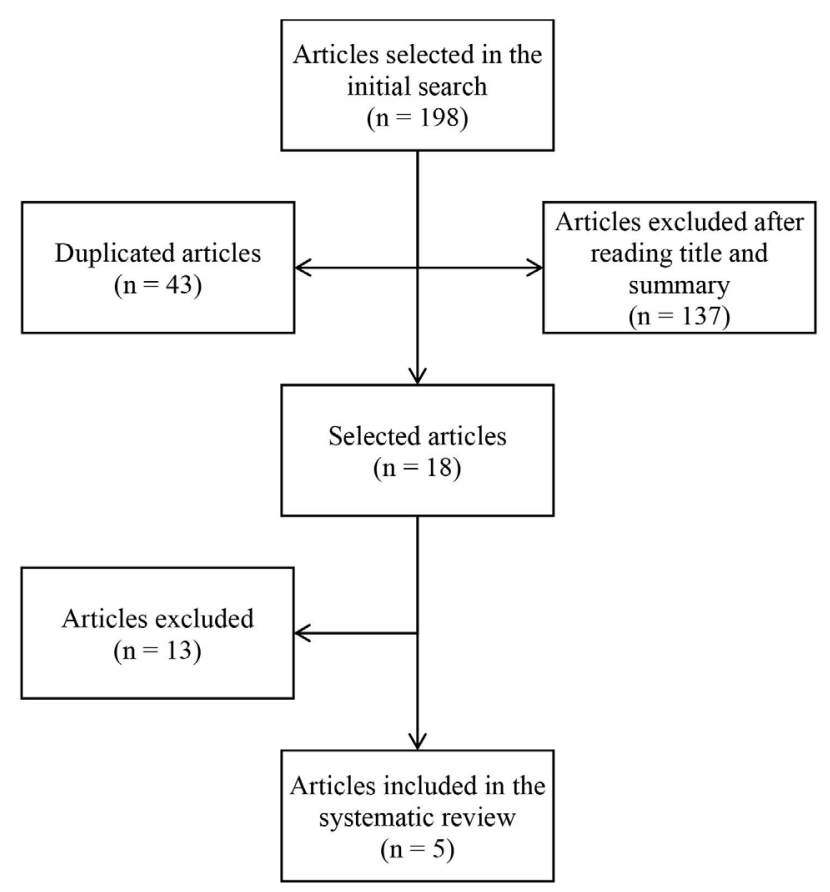

Figure 1 - Flow diagram of the article selection process 
Table 1 - Information about the selected articles in the review

\begin{tabular}{|c|c|c|c|c|c|c|c|c|}
\hline $\begin{array}{l}\text { Authors } \\
\text { (year) }\end{array}$ & Country & $\begin{array}{l}\text { Study } \\
\text { population: n }\end{array}$ & $\begin{array}{l}\text { Age } \\
\text { (mean) }\end{array}$ & $\begin{array}{l}\text { Years of } \\
\text { schooling } \\
\text { (mean) }\end{array}$ & $\begin{array}{l}\text { Dual task test } \\
\text { used }\end{array}$ & $\begin{array}{l}\text { Could the test } \\
\text { distinguish } \mathrm{MCl} \\
\text { from } \mathrm{AD} \text { ? }\end{array}$ & $\begin{array}{l}\text { Cut-off } \\
\text { score/ Test } \\
\text { performance } \\
\text { per group } \\
\text { (mean) }\end{array}$ & $\begin{array}{l}\text { Validity/ } \\
\text { Sensitivity }\end{array}$ \\
\hline $\begin{array}{l}\text { Bruce- } \\
\text { Keller et al. } \\
(2012)\end{array}$ & $\begin{array}{l}\text { United } \\
\text { States of } \\
\text { America }\end{array}$ & $\begin{array}{l}\text { MCl: } 15 \\
\text { Dementia: } 15\end{array}$ & $\begin{array}{l}\mathrm{MCl}: 78.7 \\
\text { Dementia: } \\
78.4\end{array}$ & $\begin{array}{l}\mathrm{MCl}: 16.5 \\
\text { Dementia: } \\
16.0\end{array}$ & $\begin{array}{l}\text { Gait and spelling } \\
\text { 5-letter words } \\
\text { backward (use of } \\
\text { GAITRite) }\end{array}$ & NR & NR & $N R$ \\
\hline $\begin{array}{l}\text { Persad et } \\
\text { al. (2008) }\end{array}$ & $\begin{array}{l}\text { United } \\
\text { States of } \\
\text { America }\end{array}$ & $\begin{array}{l}\text { MCl-A: } 15 \\
\text { MCl -A } \\
\text { multiple } \\
\text { domain: } 11 \\
\text { AD: } 15\end{array}$ & $\begin{array}{l}\text { MCI-A: } \\
72.5^{\star} \\
\text { MCI-A } \\
\text { multiple } \\
\text { domain: } \\
75.1 \\
\text { AD: } 77.5^{\star}\end{array}$ & $\begin{array}{l}\text { MCI-A: } \\
16.5 \\
\text { MCI-A } \\
\text { multiple } \\
\text { domain: } \\
15.8 \\
\text { AD: } 14.8\end{array}$ & $\begin{array}{l}\text { Walking trail- } \\
\text { making tests: } \\
\text { N-only numbers; } \\
\text { A- numbers in } \\
\text { ascending order; } \\
\text { B - numbers } \\
\text { and letters with } \\
\text { alternating } \\
\text { sequence. }\end{array}$ & $\begin{array}{l}\text { B test: } A D^{\star} \mathrm{MCl}-\mathrm{A} \text {, } \\
\mathrm{MCl}-\mathrm{A} \text { multiple } \\
\text { domain* } \mathrm{MCl}-\mathrm{A}\end{array}$ & NR & NR \\
\hline $\begin{array}{l}\text { Maquet et } \\
\text { al. (2010) }\end{array}$ & Belgium & $\begin{array}{l}\text { MCl: } 14 \\
\text { AD: } 6\end{array}$ & $\begin{array}{l}\text { MCl: } 73 \\
\text { AD: } 74\end{array}$ & $\begin{array}{l}\text { NR (all } \\
\text { above } 4 \\
\text { years) }\end{array}$ & $\begin{array}{l}\text { Gait and } \\
\text { countdown (use of } \\
\text { Locometrix sensor) }\end{array}$ & $\begin{array}{l}\mathrm{AD} * \mathrm{MCl}(\mathrm{GS}) \\
\mathrm{AD} \mathrm{MCI} \\
\text { (regularity of step } \\
\text { and stride length, } \\
\text { errors in cognitive } \\
\text { task) }\end{array}$ & $\begin{array}{l}\mathrm{MCl}: 1.05 \mathrm{~m} / \mathrm{s} \\
\mathrm{AD}: 0.74 \mathrm{~m} / \mathrm{s}\end{array}$ & NR \\
\hline $\begin{array}{l}\text { Muir et al. } \\
(2012)\end{array}$ & Canada & $\begin{array}{l}\text { MCl: } 29 \\
\text { AD: } 23\end{array}$ & $\begin{array}{l}\text { MCl: } 73.6^{*} \\
\text { AD: } 77.5^{*}\end{array}$ & $\begin{array}{l}\text { MCl: } 11.9 \\
\text { AD: } 12.3\end{array}$ & $\begin{array}{l}\text { Gait and naming } \\
\text { animals } \\
\text { Gait and } \\
\text { countdown, } \\
\text { subtracting } 1 \text { and } 7 \\
\text { each time }\end{array}$ & No & $\begin{array}{l}\text { Naming } \\
\text { animals: MCl: } \\
\text { 86.9, AD: } \\
81.0 \mathrm{~m} / \mathrm{s} \text { (GS) } \\
\text { Subtracting 1: } \\
\text { MCl: } 100.4 \text {, } \\
\text { AD: } 96.4 \mathrm{~m} / \mathrm{s} \\
\text { Subtracting } \\
\text { 7: } \mathrm{MCl}: 75.7 \text {, } \\
\text { AD: } 67.9 \mathrm{~m} / \mathrm{s}\end{array}$ & $\begin{array}{l}\text { Validity } \\
\text { for elderly } \\
\text { people } \\
\text { with } \mathrm{MCI} \\
(\mathrm{ICC}>0.85)\end{array}$ \\
\hline $\begin{array}{l}\text { Gillain et } \\
\text { al. (2009) }\end{array}$ & Belgium & $\begin{array}{l}\text { MCl: } 14 \\
\text { AD: } 6\end{array}$ & $\begin{array}{l}\text { MCl: } 72.8 \\
\text { AD: } 73.6\end{array}$ & $\begin{array}{l}\mathrm{MCl}: 13.6 \\
\text { AD: } 9.3\end{array}$ & $\begin{array}{l}\text { Gait (use of } \\
\text { Locometrix } \\
\text { sensor)/TUGT and } \\
\text { countdown starting } \\
\text { at } 50\end{array}$ & $\begin{array}{l}\text { TUGT: No } \\
\text { Gait with sensor: } \\
A D^{*} \mathrm{MCI}(\mathrm{GS})\end{array}$ & $\begin{array}{l}\text { TUGT: MCl: } \\
\text { 12.2, AD: } \\
\text { 22.0 s (time) } \\
\text { Gait with } \\
\text { sensor: MCl: } \\
\text { 1.0, AD: } 0.7 \\
\text { m/s (GS) }\end{array}$ & NR \\
\hline
\end{tabular}

Note: MCl: mild cognitive impairment, AD: Alzheimer's Disease, MCl-A: MCl-amnestic, TUGT: Timed Up and Go test, NR: not reported, *Difference between groups ( $p<0.05)$, GS: gait speed, ICC: intraclass correlation coefficient.

\section{Sample studied}

Three studies compared $\mathrm{MCI}$ and $\mathrm{AD}$ in mild phase (17 - 19). Bruce-Keller et al. (20) compared MCI and dementia, including AD and other types, but they did not specify the percentage of types and phases of dementia. Persad et al. (21) compared amnestic MCI, amnestic multiple-domain MCI and AD in mild phase.
Among studies included, 6-29 people per group were assessed and the mean age was between 71 and 78 years. Muir et al. (19) and Persad et al. (21) found differences in age between groups, ie, elderly people with $\mathrm{AD}$ were older. There were divergences between studies regarding gender. Two studies $(18,21)$ presented the same percentage between genders, while others presented a higher percentage of women (17) 
and men (21). Bruce-Keller et al. (20) did not specify sample's gender. No study specified if elderly people with $\mathrm{MCI}$ and $\mathrm{AD}$ were institutionalized or community-dwelling.

For MCI and dementia diagnosis, Bruce-Keller et al. (20) used the National Institute on Aging and Alzheimer's Association $(22,23)$ criteria. Persad et al. (21) used the National Alzheimer's Coordinating Center (24) criteria. The MCI Group was classified as amnestic and amnestic multiple-domain according to the Wisconsin Card Sorting Test. A poor performance indicates executive function disorder (amnestic multiple-domain). The mild phase of AD was classified by the Mini-Mental State Examination (MMSE) (25) score, between 18 and 23 points.

Maquet et al. (17) and Gillain et al. (18) defined elderly people with $\mathrm{MCI}$ as those presenting memory deficits, no significant functional change, no global cognitive impairment (minimum MMSE score of 24 points) (25) and a Clinical Dementia Rating (CDR) score of 0.5 (26). The AD diagnosis was established by the National Institute of Neurological and Communicative Disorders and Stroke/Alzheimer Disease and Related Disorders Association (NINCDSADRDA) (27), in addition to a CDR score of 1.0 and a minimum MMSE score of 20 points (mild stage).

Muir et al. (19) defined MCI as elderly people with complaint subjective memory (expressed by the patient or family), objective memory disorder as shown in cognitive tests, absence of significant functional disorder and absence of clinical dementia (28). For $\mathrm{AD}$ diagnosis, the same criteria of Maquet et al. (17) and a minimum MMSE score of 20 points (mild stage) were used.

\section{Dual task test performed}

Bruce-Keller et al. (20) used the GAITRite computerized gait analysis system to assess dual task. Gait was associated with a cognitive task of spelling five-letter words backward. There was a significant correlation between gait speed versus MMSE score, processing speed and executive function only in the Dementia Group. The MCI group showed a significant correlation between verbal fluency versus gait speed and stride length. These data are consistent with the potential of interaction between specific cognitive domains and the development of motor disturbances during the progression of dementia. The authors did not verify differences in the dual task performance between groups.

Persad et al. (21) studied walking trail-making tests associated with only numbers $(\mathrm{N})$, numbers in ascending order with additional numbered distracters (A) and numbers and letters with alternated sequence (B). The volunteers were instructed to successfully step on sequential targets. All volunteers performed the $\mathrm{N}$ test firstly to ensure the comprehension of test procedures and then a randomization between $\mathrm{A}$ and $\mathrm{B}$ tests was done. If there was any mistake, the participant returned to the last correct answer without stopping the time. Participants wore patterned shoes and a belt to prevent falls. No difference between groups was found in $\mathrm{N}$ and A tests. The AD Group performed the B test with higher time than the amnestic MCI Group. The amnestic multipledomain MCI Group took more time to perform the B test than the amnestic MCI Group.

Maquet et al. (17) and Gillain et al. (18) used the dual task test involving gait and countdown, associated with the Locometrix triaxial acceleration sensor. Elderly people were instructed to wear their own shoes. Maquet et al. (17) found significant differences between elderly people with MCI and mild phase of $\mathrm{AD}$ in gait speed, ie, elderly people with $\mathrm{AD}$ presented worse performance. Furthermore, elderly people with $\mathrm{AD}$ performed the test with shorter stride length and regularity of step and more errors in the cognitive task.

In comparison to the procedures used by Maquet et al. (17), Gillain et al. (18) specified to start counting at 50 , removed the acceleration and deceleration gait phases and performed also the Timed Up and Go test (TUGT) associated with countdown. The volunteers did not receive any instruction during tests. Elderly people with AD performed the TUGT dual task with higher time, number of stops and steps and worse qualitative evaluation compared to elderly people with MCI. Regarding the dual task test using the accelerometer, there were differences between groups in gait speed and elderly people with AD had worse stride length and regularity of step. No differences were found between groups in variations between dual task and single task performances.

Muir et al. (19) studied gait associated with three types of cognitive task (naming animals, countdown from 100 subtracting 1 and 7 each time) through the GAITRite electronic system. The test order was randomized, acceleration and deceleration phases were 
removed and no instruction was given during the test. There were no differences between MCI and AD.

With the exception of Bruce-Keller et al. (20), all studies specified the performances of dual task tests at usual speed. Only Muir et al. (19) study reported that one familiarization was done and the tests had good reliability for $\operatorname{MCI}(29,30)$.

\section{Discussion}

The present systematic review verified if tests involving gait associated with a secondary task could differ elderly people with $\mathrm{MCI}$ from $\mathrm{AD}$. Of the five studies selected, only one study did not inform if it was possible to differ the two populations (20). Although Bruce-Keller et al. did not differ MCI from AD (20), the authors brought relevant information about the relationship between specific cognitive domains and the development of motor impairments during the progression of dementia.

The knowledge about the relationship between specific cognitive functions and gait in elderly people with MCI is still limited. Some prospective studies verified that worse attention, executive function $(31-33)$ or memory performance $(31,34)$ may lead to a decline in gait speed among elderly people. In addition, a slow gait speed predicts deficits in cognitive processing speed (35), executive function and memory (36). Nevertheless, there is still no consensus about the relationship between gait variables and memory impairment $(31,35,36)$.

Three studies identified differences between MCI and $\mathrm{AD}$, through tests involving gait associated with trail-making performance in an alternating numeric and alphabetic sequence (21), countdown task(17) and countdown from fifty (18). In special, Persad et al. (21) found that the trail-making performance could only differ elderly people with MCI from AD when the test was performed in an alternating numeric and alphabetic sequence (B test). Therefore, more complex tasks seem to present more differences between these two groups. One explanation for such behavior could be the increased demand for frontal lobe functions during dual task tests, especially executive function and attention, which are highly associated with gait (37) and more affected in elderly people with AD.

Beauchet et al. (38) reported that the type of cognitive task chosen in dual task tests can influence kinematic gait parameters. The verbal fluency task requires semantic memory, which may be not fully impaired in mild phase of $\mathrm{AD}$ (39). On the other hand, the countdown task, which requires working memory, can bring more gait disturbances, because this cognitive function is impaired in early stages of $\mathrm{AD}(40)$. Beauchet et al. $(38,41)$ argued that the countdown is the secondary cognitive task that most changes kinematic gait parameters, but this influence was not seen in the study of Muir et al. (19). The authors did not find differences between elderly people with MCI and $\mathrm{AD}$ in tasks involving gait associated with naming animals and countdown from 100 subtracting 1 and 7 each time. Therefore, there is no consensus in the literature about this subject.

Guidelines for prevention of falls recommend that people with MCI should be assessed and take part of evidence-based interventions currently available for elderly people without cognitive impairment (42), as well as they should be submitted to an observational analysis of simple gait (43). However, the risk of falls in people with MCI becomes underestimated in standard screening protocols, because relevant information becomes unnoticed, as demonstrated by Muir et al. (19). In contrast to the current recommendation (42), people with MCI can not be grouped or assessed in the same manner as elderly people without cognitive impairment, due to gait disturbances associated with an increased risk of falling in people with $\mathrm{AD}$ and MCI.

The above statement is strengthened by the differences found in dual task and gait performances between elderly people with MCI and without cognitive impairment $(12,17,18,20,21)$. Although it was not the main focus of the present study, great changes in different cognitive tasks associated with gait were found in these populations.

Despite the interesting findings, it is important to pay attention to some limitations of the selected studies. In the study of Persard et al. (21), elderly people with AD were older than the MCI Group, which makes it difficult to know if the worst performance in $\mathrm{AD}$ was because of cognitive impairment or natural aging changes. Bruce-Keller et al. (20) included different types of dementias in a same group studied, which present impairment in different cognitive domains. Still, Maquet et al. (17) did not describe the procedures used in the dual task test, which makes it difficult to reproduce in future investigations.

The present review has some limitations, including few articles selected, few studies using validated tests, number of people in the studies 
and lack of information about the diagnosis of MCI and AD. A general limitation of the selected studies was the small number of participants in each group, especially in the studies of Maquet et al. (17) and Gillain et al. (18), as well as the lack of validation and cut-off scores of dual task during gait tests for elderly people with MCI and AD. Muir et al. (19) presented more details about the cognitive task and how reproduce it. It is suggested that the investigation about the secondary task performance, and not only about the gait performance, can bring important and subtle information that will help in prescribing preventive and rehabilitation interventions to these populations.

\section{Conclusion}

As conclusion, the review showed that tests involving gait associated with a task can differentiate elderly people with MCI from AD. However, it is still difficult to conclude what type of secondary cognitive task choose. More studies that differentiate elderly people with MCI from AD in mild phase using dual task tests, compare various secondary cognitive tasks, mainly involving countdown or executive function, and work with cut-off scores and validation tests are needed.

\section{Acknowledgments}

The authors acknowledge the researcher Bruno Gruninger as he helped in the selection of articles.

\section{References}

1. Alzheimer's Association. 2014 Alzheimer's Disease Facts and Figures. Alzheimers Dement. 2014;10(2):e47-92.

2. Cummings JL. Alzheimer's disease. N Engl J Med. 2004;351(1):56-67.

3. Lopez OL, Jagust WJ, DeKosky ST, Becker JT, Fitzpatrick A, Dulberg C, et al. Prevalence and classification of mild cognitive impairment in the Cardiovascular Health Study Cognition Study: Part 1. Arch Neurol. 2003;60(10):1385-9.
4. Petersen RC. Mild cognitive impairment as a diagnostic entity. J Intern Med. 2004;256(3):183-94.

5. Li H, Li J, Li N, Li B, Wang P, Zhou T. Cognitive intervention for persons with mild cognitive impairment: a meta-analysis. Ageing Res Rev. 2011;10(2):285-96.

6. Kato-Narita EM, Nitrini R, Radanovic M. Assessment of balance in mild and moderate stages of Alzheimer's disease. Arq Neuropsiquiatr. 2011;69(2A):202-7

7. Verghese J, Lipton RB, Hall CB, Kuslansky G, Katz MJ, Buschke H. Abnormality of gait as a predictor of non-Alzheimer's dementia. N Engl J Med. 2002;347(22):1761-8.

8. Buracchio T, Dodge HH, Howieson D, Wasserman D, Kaye J. The trajectory of gait speed preceding mild cognitive impairment. Arch Neurol. 2010;67(8):980-6.

9. Liu-Ambrose T, Ashe MC, Graf P, Beattie BL, Khan KM. Mild cognitive impairment increases falls risk in older community-dwelling women. Phys Ther. 2008;88(12):1482-91.

10. Zidan M, Arcoverde C, Araujo NB, Vasques P, Rios A, Laks J, et al. Alterações motoras e funcionais em diferentes estágios da doença de Alzheimer. Rev Psiquiatr Clin. 2012;39(5):161-5.

11. Montero-Odasso M, Muir SW, Speechley M. Dual task complexity affects gait in people with mild cognitive impairment: the interplay between gait variability, dual tasking, and risk of falls. Arch Phys Med Rehabil. 2012;93(2):293-9.

12. Muir SW, Speechley M, Wells J, Borrie M, Gopaul K, Montero-Odasso M. Gait assessment in mild cognitive impairment and Alzheimer's disease: The effect of dual-task challenges across the cognitive spectrum. Gait Posture. 2012;35(1):96-100.

13. Perrochon A, Kemoun G, Watelain E, Berthoz A. Walking Stroop carpet: an innovative dual-task concept for detecting cognitive impairment. Clin Interv Aging. 2013;8:317-28.

14. Sheridan PL, Solomont J, Kowall N, Hausdorff JM. Influence of executive function on locomotor function: divided attention increases gait variability in Alzheimer's disease. J Am Geriatr Soc. 2003;51(11):1633-7.

15. Brucki SM, Nitrini R, Caramelli P, Bertolucci PHF, Okamoto IH. Sugestões para o uso do mini-exame do estado mental no Brasil. Arq Neuro-Psiquiatr. 2003;61(3B):777-81. 
16. Carvalho VA, Caramelli P. Brazilian adaptation of the Addenbrooke's Cognitive Examination-Revised (ACER). Dement Neuropsychol. 2007;1(2):212-6.

17. Maquet D, Lekeu F, Warzee E, Gillain S, Wojtasik V, Salmon E, et al. Gait analysis in elderly adult patients with mild cognitive impairment and patients with mild Alzheimer's disease: simple versus dual task: a preliminary report. Clin Physiol Funct Imaging. 2010;30(1):51-6.

18. Gillain S, Warzee E, Lekeu F, Wojtasik V, Maquet D, Croisier JL, et al. The value of instrumental gait analysis in elderly healthy, MCI or Alzheimer's disease subjects and comparison with other clinical tests used in single and dual-task conditions. Ann Phys Rehabil Med. 2009;52(6):453-74.

19. Muir SW, Speechley M, Wells J, Borrie M, Gopaul K, Montero-Odasso M. Gait assessment in mild cognitive impairment and Alzheimer's disease: the effect of dual-task challenges across the cognitive spectrum. Gait Posture. 2012;35(1):96-100.

20. Bruce-Keller AJ, Brouillette RM, Tudor-Locke C. Assessment of cognition, physical performance, and gait in the context of mild cognitive impairment and dementia. J Am Geriatr Soc. 2012;60(1):176-7.

21. Persad CC, Jones JL, Ashton-Miller JA, Alexander NB, Giordani B. Executive function and gait in older adults with cognitive impairment. J Gerontol A Biol Sci Med Sci. 2008;63(12):1350-5.

22. Albert MS, DeKosky ST, Dickson D, Dubois B, Feldman HH, Fox NC, et al. The diagnosis of mild cognitive impairment due to Alzheimer's disease: Recommendations from the National Institute on Aging and Alzheimer's Association workgroup. Alzheimers Dement. 2011;7(3):270-9.

23. McKhann GM, Knopman DS, Chertkow H, Hyman BT, Jack Jr CR, Kawas CH, et al. The diagnosis of dementia due to Alzheimer's disease: Recommendations from the National Institute on AgingAlzheimer's Association Workgroups on Diagnostic Guidelines for Alzheimer's Disease. Alzheimers Dement. 2011;7(3):263-9.

24. NACC Uniform Date Set (UDS) Coding Guidebook (Version 1.2, March 2006). Seattle: University of Washington; 2006.68 p. [cited 2015 Sep 1]. Available from: http://tinyurl.com/ztw4ohf.
25. Folstein MF, Folstein SE, McHugh PR. "Mini-mental state". A practical method for grading the cognitive state of patients for the clinician. J Psychiatr Res. 1975;12(3):189-98.

26. Morris JC. The clinical dementia rating (CDR): current version and scoring rules. Neurology. 1993;43(11):2412-4.

27. McKhann G, Drachman D, Folstein M, Katzman R, Price D, Stadlan EM. Clinical diagnosis of Alzheimers disease: Report of the NINCDS-ADRDA Work Group under the auspices of Department of Health and Human Services Task Force on Alzheimers Disease. Neurology. 1984;34(7): 939-44.

28. Winblad B, Palmer K, Kivipelto M, Jelic V, Fratiglioni L, Wahlund LO, et al. Mild cognitive impairment-beyond controversies, towards a consensus: report of the International Working Group on Mild Cognitive Impairment. J Intern Med. 2004;256(3):240-6.

29. Montero-Odasso M, Casas A, Hansen K, Gutmanis I, Wells J, Borrie M. Test-Retest reliability of quantitative gait analysis in people with mild cognitive impairment. Can J Geriatr Med Psychiatr. 2007;10(3):33-4.

30. Montero-Odasso M, Casas A, Hansen KT, Bilski P, Gutmanis I, Wells JL, et al. Quantitative gait analysis under dual-task in older people with mild cognitive impairment: a reliability study. J Neuroeng Rehabil 2009;6:35.

31. Holtzer R, Wang C, Lipton R, Verghese J. The protective effects of executive functions and episodic memory on gait speed decline in aging defined in the context of cognitive reserve. J Am Geriatr Soc. 2012;60(11):2093-8.

32. Atkinson HH, Rosano C, Simonsick EM, Williamson JD, Davis C, Ambrosius WT, et al. Cognitive function, gait speed decline, and comorbidities: the health, aging and body composition study. J Gerontol A Biol Sci Med Sci. 2007;62(8):844-50.

33. Verghese J, Kuslansky G, Holtzer R, Katz M, Xue X, Buschke $H$, et al. Walking while talking: effect of task prioritization in the elderly. Arch Phys Med Rehabil. 2007;88(1):50-3.

34. Watson NL, Rosano C, Boudreau RM, Simonsick EM, Ferrucci L, Sutton-Tyrrell K, et al. Executive function, memory, and gait speed decline in well-functioning older adults. J Gerontol A Biol Sci Med Sci. 2010;65(10):1093-100. 
35. Inzitari $\mathrm{M}$, Newman $\mathrm{AB}$, Yaffe $\mathrm{K}$, Boudreau R, Rekeneire N, Shorr R, et al. Gait speed predicts decline in attention and psychomotor speed in older adults: the health aging and body composition study. Neuroepidemiology. 2008;29(3-4):156-62.

36. Mielke MM, Roberts RO, Savica R, Cha R, Drubach DI, Christianson T, et al. Assessing the temporal relationship between cognition and gait: slow gait predicts cognitive decline in the mayo clinic study of aging. J Gerontol A Biol Sci Med Sci. 2013;68(8):929-37.

37. Sheridan PL, Hausdorff JM. The role of higher-level cognitive function in gait: Executive dysfunction contributes to fall risk in Alzheimer's disease. Dement Geriatr Cogn Disord. 2007;24(2):125-37.

38. Beauchet O, Dubost V, Aminian K, Gonthier R, Kressig RW. Dual-task related gait changes in the elderly: does the type of cognitive task matter? J Mot Behav. 2005;37(4):259-64.

39. Hausdorff JM. Stride variability beyond length and frequency. Gait Posture. 2004;20(3):304.
40. Hittmair-Delazer M, Semenza C, Denes G. Concepts and facts in calculation. Brain. 1994;117(Pt 4):715-28.

41. Beauchet O, Dubost V, Gonthier R, Kressig RW. Dualtask-related gait changes in transitionally frail older adults: the type of the walking associated. Gerontology. 2005;51(1):48-52.

42. Shaw FE. Prevention of falls in older people with dementia. J Neural Transm (Vienna). 2007;114(10):1259-64.

43. Panel on Prevention of Falls in Older Persons, American Geriatrics Society and British Geriatrics Society. Summary of the updated American Geriatrics Society/ British Geriatrics Society clinical practice guideline for the prevention of falls in older persons. J Am Geriatr Soc. 2011;59(1):148-57.

Received in 10/08/2015 Recebido em 08/10/2015

Approved in 08/18/2016 Aprovado em 18/08/2016 